\title{
13 \\ Atoms and Airports: Towra Point
}

Bernie Clarke had grown up on the Georges River. Born in 1921, he lived most of his life at Oyster Bay, on the southern shore of the river, just opposite the mouth of Oatley Bay. He had followed the family profession and become a commercial fisherman after serving in Papua New Guinea in World War II. So he knew about mangroves, tropical and temperate. Bernie had begun his activist career in 1952 when he was arrested for setting up a roadblock to try to stop the oil refinery being built at Kurnell in Botany Bay. A Sutherland man, he was the archetype of all the older Georges River activists. He would have been comfortable in the Picnic Point Regatta Association (PPRA) - and perhaps he was. Like the early campaigners for the national park, Bernie was the activist in his family. His wife, Belle, was a strong supporter of all his campaigns but, in 1996, was said to be 'operating quietly behind the scenes' in the same way that Min Jacobsen and Eileen Stills had done. ${ }^{1}$ Bernie was a fisherman who fished for pleasure as well as a job, a working-class man who knew the beaches, tides and fish up and down the river and into the bay.

Yet Bernie Clarke - like all the local residents in Sutherland - was faced with two of the most difficult problems of modernity. Compared to the councils along the northern shores, Sutherland had far fewer conflicts about reclamations because it had attempted far fewer of them; it had fewer people to generate garbage, fewer expensive yachts and powerboats

1 Borschmann, 'Guardian of Botany Bay', 10; Goodall and Cadzow, Rivers and Resilience. 
to dredge for moorings and fewer bays to reclaim. And, where volumes of garbage did become a problem, Sutherland had the new Menai tip within its own borders.

Precisely because of its low population, however, Sutherland had been made the site of Australia's first nuclear reactor, an extreme expression of the military uses of land that had characterised the government's acquisition of Holsworthy. The High Flux Australian Reactor, perched on an escarpment at Lucas Heights, on the watershed between the Woronora River and Mill Creek, and operating from 1958, was a Cold War military experiment in nuclear fuel creation rather than an experiment in the production of electricity. In the end, its only acknowledged role was in the production of radioactive material for medical purposes and, at times, for environmental research. Through the early 1950s, British atomic testing in Western and South Australia had gone largely unnoticed by Australians, but the severe problems arising from the US Bravo test in the South Pacific at the Marshall Islands in March 1954 had alerted many people to the unpredictable and uncontrolled effects of radioactivity. ${ }^{2}$ So the Lucas Heights reactor was given an uneasy welcome, and fears circulated about what toxic waste it might be releasing into the Woronora River, Mill Creek and downstream. ${ }^{3}$ The original waste pipeline went into the Woronora River, but was later rerouted to go up, over the river and into waste storage on the eastern ridge of the Woronora. Mill Creek rises in the nearby toxic waste depot, and also receives some surface storm water from the reactor grounds. Tests done in later years (after 1980) showed that the natural pooling structure of Mill Creek had kept any more dangerous material at its source. ${ }^{4}$

This nuclear anxiety was compounded by plans discussed from the early 1960 s to build a second airport on Towra Point, the sandy promontory that sheltered the mouth of the Georges River as it entered Botany Bay. Aircraft noise and pollution from Kingsford Smith Airport, opened in 1933, had been causing great trouble to the area's residents. Fishermen like Bernie Clarke were acutely aware of how the wave patterns were altered by the runway protruding into Botany Bay and he was later to make dredging a major target.

\footnotetext{
2 Niedenthal, 'A Short History'.

3 'Pollution from Atomic Plants', Canberra Times, 5 August 1969, 8. Reporting Denis Winston's evidence at the Senate Select Committee, under questioning from Senator Mulvihill as well as that by H. C. Hunt, Bankstown's chief health inspector, about both the reactor and the toxic industrial waste depot located close to it. See Senate Select Committee on Water Pollution, Minutes of Evidence, vol. 20, 4637.

4 Robert Haworth, a member of that water quality research team, pers. comm., June 2020.
} 


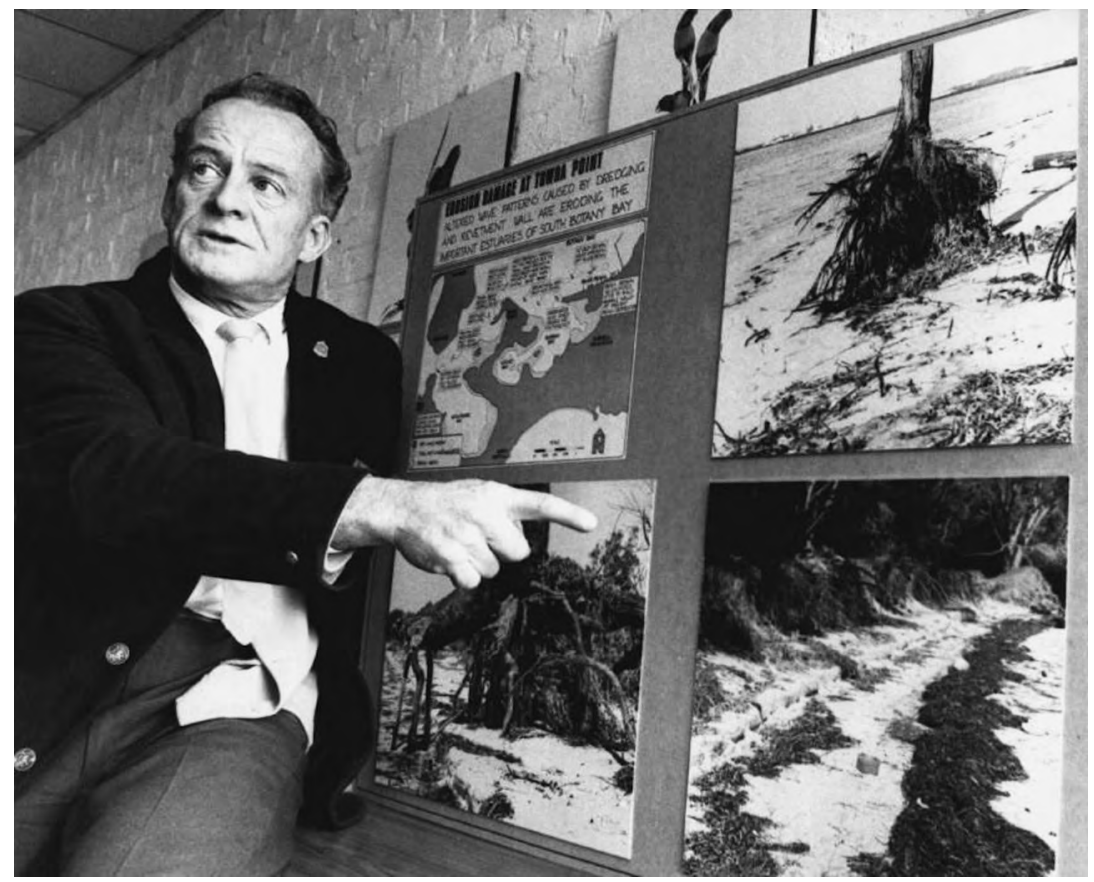

Figure 13.1: Bernie Clarke in 1975 demonstrating how dredging was damaging the foreshore of the 'important estuaries of south Botany Bay'.

Obituary, St George and Sutherland Shire Leader, 17 January 2019. Courtesy of Nine Publishing.

Moreover, as discussed in earlier chapters, there were people on the Sutherland Shire Council who were sympathetic to the new ecology. So, when reclamations had been attempted, there were councillors who spoke out against them. Notably, in 1965 and 1966, when the Georges River National Park Trust and Sutherland Shire planned to reclaim two large low-lying swamps at Mickey's Point and Alfords Point on the southern bank of the river, the plan was opposed by the chair of the Parks and Playgrounds Committee, ALP Alderman Kevin Skinner, who commented ruefully that:

The Council's policy is that the flat areas of the river foreshores should be used for playgrounds and this may or may not be bad. We would not like to see the National Park turned into one big oval or a Coney Island. I oppose the whole of the Georges River 
being treated as a reclamation area. I hope the river will be allowed to stay in its natural state for the use of future generations. It will be a $\sin$ if this is not done. ${ }^{5}$

This second airport was to be a particular Sutherland anxiety, despite holding some implications for the northern shores of the river. The proposed flight path - and all its attendant noise - was not only planned to go to the south-west, thus crossing all of Sutherland, but also planes would be travelling low right over the only place on that southern side of the river that had begun to rise in value: the canal suburb of Sylvania Waters. The airport plan brought the dispersed population together like nothing else. The major strategy of Sutherland Shire in supporting - and indeed fanning - this local opposition to the airport was to demonstrate what this flight path noise would mean. ${ }^{6}$ A meeting of over 1,400 people was held in the car park at Miranda Fair in 1968 while a recording of jet engines under full throttle was played through loudspeakers. A council station wagon was then fitted with loudspeakers and driven round the shire streets. Arthur Gietzelt described the process:

Council's ganger and former councillor, Jimmy Stansell, in ear-muffs, drove the system over 700 miles around the shire, broadcasting the noise at about 40 times the level of ordinary public address broadcasting. The effect was dramatic. When the vehicle parked in shopping centres and let off a blast, the shopkeepers promptly appeared and signalled the driver on with rude gestures - if only we could get rid of jet noise that easily! When it parked outside blocks of home units, the reaction was similarly spontaneous - windows and doors slammed shut. The minuteand-a-half broadcast of jet noise was followed immediately by an apology from Council and an explanation of the fact that unless a protest was made, the noise could well become a daily occurrence in the life of the shire's residents. ${ }^{7}$

5 'Survey Planned for Waterways', St George and Sutherland Shire Leader (hereafter Leader), 14 December 1966, 11. Later, Skinner was mayor for six terms, 1973-74 and 1982-86.

6 Cullis, 'Holsworthy'; 'Homes to be Under Jet Alley', Leader 19 July 1967, 1; 'Editorial: What Is Going on at Towra?', Leader, 19 July 1967, 2.

7 Gietzelt, Sticks and Stones. 


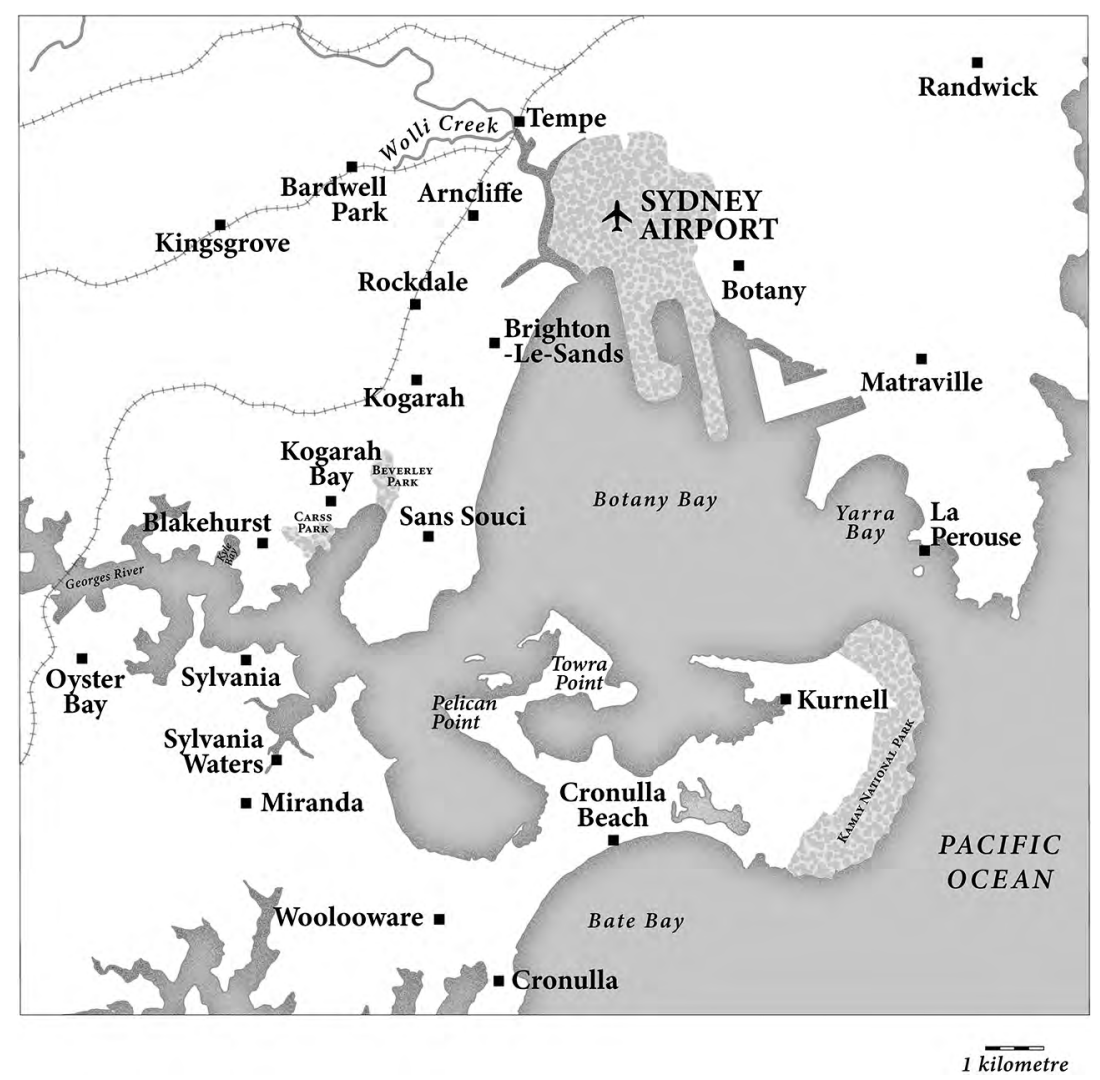

Map 13.1: Towra Point and Botany Bay.

Cartography: Sharon Harrup.

Yet, despite the very local concerns, this dispute had implications for all urban residents in relation to noise and environmental justice. With more success than the Lime Kiln Bay campaigners had in their appeal to the Municipal Employees' Union, the Sutherland campaigners against the Towra Point airport called on the support of the Amalgamated Metal Workers Union who saw themselves as representing the residents of Kogarah, Rockdale and Hurstville as well as those in the Sutherland area. The union was particularly concerned to support the residents in opposing the second airport - or indeed any airport extension - because they wanted to stop the spread of high-rise or even medium-density development from eroding residents' amenities. ${ }^{8}$

8 'Extension of Sydney Airport Suggested: Union Represents Residents', Canberra Times, 14 December 1973, 12. 
There was also a widely endorsed environmental concern about the vulnerability of Towra Point. This sandy promontory had been cleared in the 1850s for Thomas Holt's grazing stock and the bays reshaped for his oyster leases, which had been managed by William Rowley, the Aboriginal man who later moved upriver into the Salt Pan Creek Aboriginal community, contributing to their demands for civil rights in the 1920s. ${ }^{9}$ Holt's attempts at commercial uses had eventually failed, however, and Towra Point had been little used, with its wetlands no longer disturbed and its vegetation left to regrow unharvested. By the 1960s, it looked like wilderness and certainly offered shelter for birds and aquatic species. But it was being threatened by expanding commercial activities in Botany Bay, such as dredging to enable the passage of large tankers to the new oil refineries, potential oil spills and the continual wash of the ships as they moved.

Bernie Clarke was a tireless advocate for the conservation values of the promontory, arguing strongly against further dredging and in support of the now wildly beautiful place. He knew little, however, about the wildlife or vegetation there. Characteristic of many of the Georges River campaigners, Clarke as a fisherman could tell you about the riverbed and the sea creatures there but not about the land creatures or their habitat. During this campaign against the second airport, however, he was approached by Arnold McGill, an amateur ornithologist, who had been surveying birdlife on Botany Bay. McGill introduced Clarke to the long journey of the migratory waders - birds that flew over 20,000 kilometres to get to Botany Bay from their northern hemisphere breeding grounds in Siberia, Alaska, Asia and the Arctic Circle. ${ }^{10}$ Clarke appreciated the importance of the birds of the area, taking up McGill's concern and adding the protection of birdlife to the campaign to save Towra Point. Yet he admitted to conservationist Gregg Borschmann that his battles to save the river and bay up to then had been based on his lifelong love of the river as a fisherman:

I didn't know the difference between a pigeon and a wading bird, or an angophora and a blackbutt tree. Back then, a bird was a bird and a tree was a tree. ${ }^{11}$

9 Goodall and Cadzow, Rivers and Resilience; Irish, Hidden in Plain View, 130.

10 Borschmann, 'Guardian of Botany Bay'.

11 Bernie Clarke, quoted in Borschmann, 'Guardian of Botany Bay', 12. 


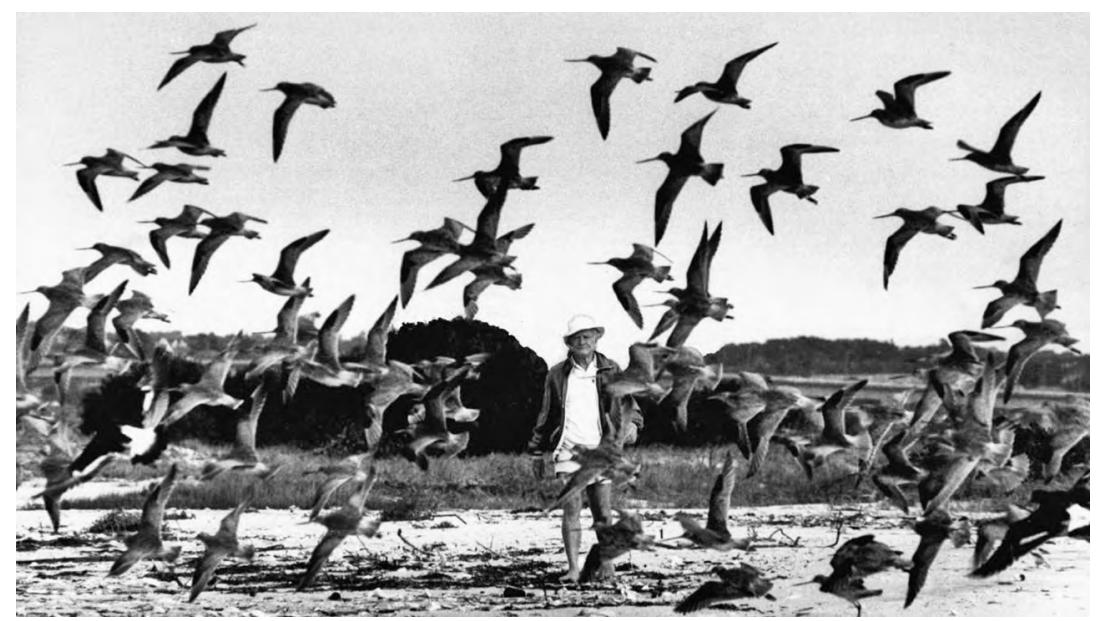

Figure 13.2: Bernie Clarke with migratory wading birds at Towra Point in 1990.

Photographer: Robert Pearce, Fairfax. Obituary, St George and Sutherland Shire Leader, 17 January 2019. Courtesy of Nine Publishing.

Clarke was joined by others across the shire and on the northern shores as well, including the Cooks River Valley Association. ${ }^{12}$ The pressure mounted by the conservation argument (and, perhaps, local reaction to the aircraft noise demonstration) led Liberal Prime Minister John Gorton to retreat in 1969 from the plan to put the second airport on Towra Point, fearing the loss of votes in the coming elections. ${ }^{13}$ Whitlam's Labor Party won government in 1972, which saw Gietzelt in federal parliament as a senator for New South Wales, and an enthusiastic environment minister, Moss Cass. With continuing lobbying from the Sutherland Shire Council and residents, the Whitlam government set about trying to protect Towra Point. ${ }^{14}$ The airport plan was discarded permanently and the federal government tried to convince the state government (as state governments hold all power over land under the Australian Constitution) to purchase the promontory from its three private owners. The conservative state government refused to do so. In May 1973 Whitlam announced the dramatic decision that the federal government would compulsorily acquire the land through its Department of Services and Property under the Land Acquisition Act and would set the land aside as a national park.

12 Tyrrell, River Dreams, 152; Muir, A History of Cooks River, 8, 172.

13 Borschmann, 'Guardian of Botany Bay'.

14 Wildlife Park Plans', Canberra Times, 8 May 1974, 3; “"Threat” to Historic Site', Canberra Times, 27 July $1974,7$. 
The UNESCO Ramsar Convention was repeatedly raised by Whitlam and Cass, but this international treaty carried no actual power for the Australian Government. It would be a decade before the High Court would decide (in the Franklin Dam case) that the federal government did indeed have foreign affairs power to conserve internationally valued heritage land, so this decision to acquire Towra Point was a groundbreaking precursor to later environmental activism. As Moss Cass explained: 'This will be the first time that any Australian Government has owned and managed land for nature conservation purposes within a State. ${ }^{35}$ Moreover, Towra Point was a complex area, with many different types of valuable environmental sites including sand dunes, wetland and revegetated clearing. All these types of habitat were mentioned in initial announcements of the attempts to have the area protected.

Yet the press focused on the key environmental element that had become dominant in the many concurrent environmental conflicts along the river: mangroves. This was reported very directly in the local press as an issue about mangroves and it was picked up in the national press, with The Canberra Times headlining its story about the acquisition 'Mangrove Area to be Reserve'. ${ }^{16}$ While the detailed statements of the federal minister and activists like Bernie Clarke explained the complexity of the site, by 1975 the mangroves there had become iconic in all estuarine disputes - they were a metonym, standing in for the whole issue no matter how much more complex it might be.

For Bernie Clarke, too, the mangroves were the key element of the landscape. He may not have known many botanical details about them before the mid-1960s, but he knew about their role in nurturing the fish that he caught. He devoted the rest of his life not only to protecting the mangroves but also to educating people about them and replanting them. He was involved in many campaigns in later years, but what was always closest to his heart was protecting the mangroves. He led school trips along newly constructed boardwalks through the mangroves and he encouraged children to plant mangrove seedlings.

15 'Mangrove Area to be Reserve', Canberra Times, 21 March 1975, 3.

16 Ibid. 


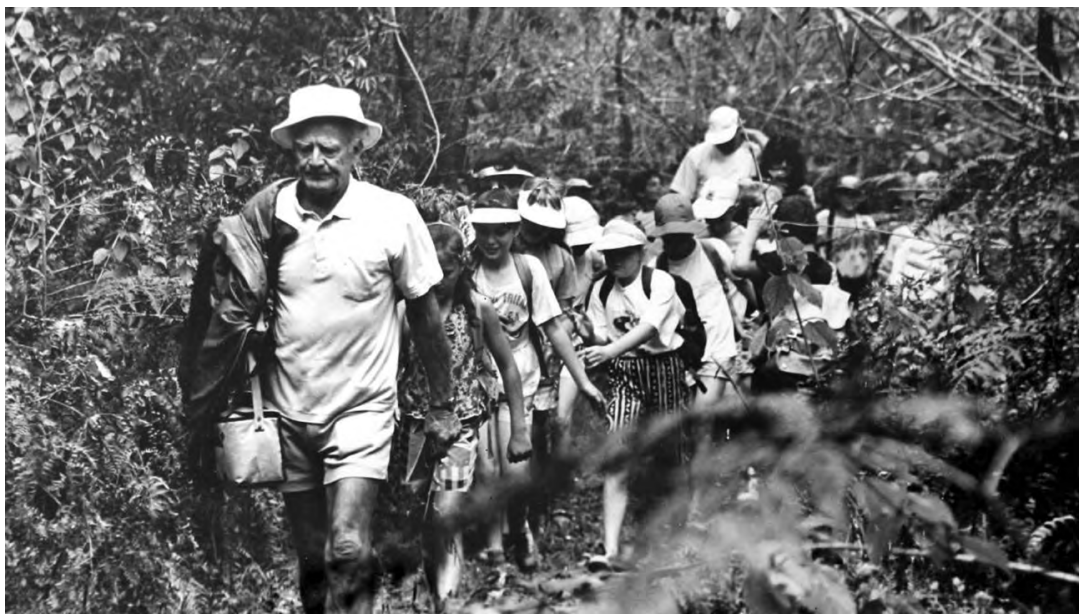

Figure 13.3: Bernie Clarke showing Towra Point mangroves to local primary school students, 1989.

Obituary, St George and Sutherland Shire Leader, 17 January 2019. Courtesy of Nine Publishing.

From the early 1990s, Bernie Clarke - and the many school children and fellow conservationists who helped him - planted more than 7,500 mangrove plants on Towra promontory. When Borschmann asked Clarke how he wanted to be remembered, he replied: 'If someone comes along and says, "Bernie Clarke planted those mangroves," that's all the satisfaction I want'. ${ }^{17}$

17 Borschmann, 'Guardian of Botany Bay', 13. 
This text is taken from Georges River Blues: Swamps, Mangroves and Resident Action, 1945-1980, by Heather Goodall, published 2022, The Australian National University, Canberra, Australia.

doi.org/10.22459/GRB.2021.13 